\title{
CANCER REPERCUSSIONS ON PLAY IN CHILDREN: IMPLICATIONS FOR NURSING CARE ${ }^{1}$
}

\author{
Liliane Faria da Silva², Ivone Evangelista Cabral ${ }^{3}$
}

\footnotetext{
${ }^{1}$ Extracted from the thesis - Meaning of playing for families of children on cancer treatment: implications for nursing care, presented at the Anna Nery School of Nursing (EEAN), Universidade Federal do Rio de Janeiro (UFRJ), 2012.

2 Ph.D. in Nursing. Assistant Professor, Department of Maternal Child and Psychiatric, Aurora Afonso Costa Nursing School, Universidade Federal do Rio de Janeiro. Rio de Janeiro, Rio de Janeiro, Brazil. E-mail: 1ili.05@hotmail.com

${ }^{3}$ Ph.D. in Nursing. Associate Professor, Department of Maternal Child Nursing, School of Nursing EEAN/UFRJ. Rio de Janeiro, Rio de Janeiro, Brazil. E-mail: icabral44@hotmail.com
}

\begin{abstract}
The study aimed to identify cancer repercussions on play among children in oncological treatment. This was qualitative research implemented according to a creative and sensible method. Twenty-two family members of seven children in ambulatory cancer treatment in a hospital from Rio de Janeiro participated. Data production occurred in family members' houses, from September 2011 to May 2012. The data were analyzed according to discourse analysis. Two thematic units emerged: childhood cancer - a happening about play; and playing in the course of the child's illness and treatment: a possibility to rescue care of maintaining life. Maintaining play is a child's need that demands nursing care of a different nature, to assure the right to play during treatment, in order to reduce traumas and damage to their development.
\end{abstract}

DESCRIPTORS: Play and playthings. Pediatric nursing. Cancer.

\section{AS REPERCUSSÕES DO CÂNCER SOBRE O BRINCAR DA CRIANÇA: IMPLICAÇÕES PARA O CUIDADO DE ENFERMAGEM}

RESUMO: Objetivou-se identificar as repercussões do câncer sobre o brincar da criança em tratamento oncológico. Pesquisa qualitativa implementada segundo o método criativo e sensível. Participaram 22 familiares de sete crianças com câncer em tratamento ambulatorial em um hospital do Rio de Janeiro. A produção de dados ocorreu nas residências dos familiares, no período de setembro de 2011 a maio de 2012. Os dados foram analisados pela análise de discurso. Emergiram duas unidades temáticas: o câncer infantil - um acontecimento sobre o brincar; e o brincar no curso do adoecimento e tratamento da criança: uma possibilidade de resgate do cuidado de manutenção da vida. A manutenção da brincadeira é uma necessidade da criança que demanda cuidados de enfermagem de diferentes naturezas, para assegurar o direito de brincar durante o tratamento, com vistas à redução de traumas e prejuízos para o seu desenvolvimento.

DESCRITORES: Jogos e brinquedos. Enfermagem pediátrica. Câncer.

\section{LAS REPERCUSIONES DEL CÁNCER SOBRE EL JUGAR DEL NIÑO: IMPLICACIONES PARA EL CUIDADO DE ENFERMERÍA}

\begin{abstract}
RESUMEN: Se intentó identificar las repercusiones del cáncer sobre el jugar del niño em tratamiento oncológico. Investigación cualitativa implementada según el método creativo y sensible. Participaron 22 familiares de siete niños con cáncer en tratamiento ambulatorio en un hospital de Río de Janeiro. La producción de datos ocurrió en las casas de los familiares, de septiembre de 2011 a mayo de 2012. Los datos fueron analizados por el análisis del discurso. Emergieron dos unidades temáticas: el cáncer infantil - un acontecimiento sobre el jugar; el jugar en el curso del proceso de contracción de una enfermedad y tratamiento del niño: una posibilidad de rescate del cuidado de mantenimiento de la vida. El mantenimiento de los juegos es una necesidad del niño que demanda cuidados de enfermería de diferentes naturalezas, para garantizar el derecho a jugar durante el tratamiento, objetivando la reducción de traumas y prejuicios para su desarrollo.
\end{abstract}

DESCRIPTORES: Juego e implementos de juego. Enfermería pediátrica. Cáncer. 


\section{INTRODUCTION}

Although cancer in children is considered rare when compared to adults, it is currently ranked as the first cause of death by disease in children up to five years of age, second only to deaths due to violence and accidents. The National Cancer Institute (NCI) has estimated for the year 2012 a total of 11,530 new cases of cancer in children and adolescents up to 19 years of age. ${ }^{1}$ With the diagnosis of childhood cancer, the child begins to have special needs, which are caused both by the course of the disease and the type of treatment. ${ }^{2-3}$

Children with special health care needs (CSHCN) have or are at increased risk for developing their physical fitness, their development, or their behavior, whether the special needs are of a temporary or chronic nature, which generally demands a type and a quantity of health services beyond those required by other children. These health needs require care that, when not properly performed, directly interferes with the survival of these children. ${ }^{3-4}$

During the cancer treatment, the child is subjected to several examinations, prolonged hospitalization time for chemotherapy, radiotherapy, surgery and drug therapy that can cause limitations, in addition to physical and psychological disabilities. The comings and goings to the inpatient treatment centers, as well as to outpatient services, expose the children to pain and suffering, and even cause interruptions in school activities and set them apart from the social and family life, and thus interfere with their ability and desire to play. ${ }^{1-5}$

For all the impact that cancer brings to the child, the nurse who takes care of him/her should, along with the family, pursue strategies to maintain the best possible quality of life during treatment. This should be done through humane care that permeates the child's universe, in which specific materials and therapeutic resources are not the main focus. ${ }^{6}$ In this context, there are possibilities to recover aspects vital to the child's development and the need to play at any stage, both for their individual development as well as during the course ofillness.

Playing, besides being a demand of care in order to promote child development, is also a source of pleasure, becoming a kind of assistance that calls one to life and helps maintain the lives of these children. In this sense, during the period of cancer treatment, it becomes relevant to adopt nursing care focused not only on the treatment of the disease, but also in maintaining the child's lifestyle. ${ }^{2}$

With respect to the typology of nursing care, this study assumed the theoretical conceptions of the French nurse Françoise Collière, who described two types of care: a) usual or maintenance care, on a daily basis, whose functions are aimed at maintaining and continuing life and everything that contributes to the development and survival of human beings; and $b$ ) reparative care, aimed at investigating the causes of the disease, in addition to limiting, combating and treating it. . $^{7-8}$

When it comes to the children affected by a disease such as cancer, it is important to note that, in the conception of Collière, care and treatment do not have the same nature. Treatment targets the disease, while care is focused on the person and the maintenance of his/her life. In this sense, when the disease sets in and reaches a certain organ or disturbs the whole body of the child, it affects not only the physical body.-8 Primarily, it reaches what it is "to be" a child, interfering with his ability to live and fully develop his potential.

In order to stimulate the maintenance of child development during cancer treatment, boosted by the extension of the child's own play activities performed during his/her daily life, the nurse must transcend reparative care, which is meant for the treatment of the disease, and invest in a kind of care capable of maintaining life.

Currently studies on play in children with cancer $^{9-11}$ highlight its benefits during hospitalization. However, play gets little visibility in the literature when it comes to the home and the community, and regarding the inclusion of the family perspective in these scenarios.

In this sense, this study addressed the context of life of children with cancer in order to identify the impact that the disease had on the dimensions of play in their lives, so as to seek actions and strategies along with their family members, to ensure the best conditions for the child's development and quality of life during the course of treatment. The following objective was defined: to identify the repercussions of cancer on play in children undergoing cancer treatment. 


\section{METHODS}

The qualitative research was conducted in accordance with the Creative and Sensitive Method (CSM), which has its foundations based on the following triad: group discussion, participant observation and dynamics of creativity and sensibility. ${ }^{2-3,12}$

During the dynamics of creativity and sensibility, survey participants prepare an artistic type production that is mobilized by an issue generated by debate related to the study objective. This artistic production motivates participants to speak for themselves through the producing action, and hence to evoke their values and beliefs related to the subjects whose interests are common to group. . $^{2-3,12}$

Based on the guidelines of the method, two dynamics for creativity and sensibility were selected for the development of this research, as follows: lifeline and speaker map. The generating questions for discussion were: "locate your experience of play in the timeline of your life ... and tell us about how this experience has influenced play and playthings in the life of (child's name)" and "which places and with which people does (child's name) usually play when not hospitalized"?

The participants were composed of 22 relatives of seven children with cancer in outpatient treatment at an oncology hospital located in the municipality of Rio de Janeiro. The inclusion criteria for the study were: a) Family of school age children in outpatient cancer treatment at the time of the recruitment; b) residing in the city of Rio de Janeiro or from nearby municipalities up to 100 miles away from the treatment center. We excluded from the study: a) families of children who resided in support homes, since the study was focused on the home environment; $b$ ) family members under 12 years of age; and c) family members presenting psychiatric compromise, as this could interfere with the reliability of the survey data.

The option to work with families of school age children, from six to 12 years, was due to the fact that this is the age at which the child affiliates with peers of the same age. Therefore, the sense of belonging to a group is very important, moreover, the child's games involve fantasies, and physical and intellectual skills. ${ }^{13}$

The anonymity of the family and the children was also guaranteed. For this, children were identified in the study with a number according to the order of their participation in the research, and the identification of the sex of the child was made by using the respective gender-specific pronoun SHE for the girls and HE for the boys. The relatives also received a numeric code that followed their order of participation in the dynamics.

The selection and recruitment of subjects occurred at a pediatric oncology ward where the children had their treatment, and the data collection phase occurred at the houses of the children performing outpatient treatment in that institution, from September 2011 to May 2012.

It is noteworthy that two dynamics were performed with each of the seven families. It is clarified that the 22 subjects were distributed in seven families as follows: for child 1, a grandmother, the mother and three brothers; for child 2, his mother and two sisters; for child 3 , both parents and two aunts; for child 4, his mother and two sisters; for child 5, her mother and a sister; for child 6 , a grandmother and two aunts; and finally for child 7, both parents participated.

The study was approved by the Board of Ethics of the institution in which the children were receiving oncological treatment (CAAE Protocol. 0016.0.007.00-11/Report no. 44/11) and all participants signed the Terms of Free and Informed consent after becoming aware of the objectives of the study.

As regards to criteria to terminate the fieldwork, we used the sampling process of theoretical saturation. In this case, the researcher stops collecting data when he/she considers that the interaction in the field is no longer providing new elements to clarify or deepen the conceptualization of the study object. ${ }^{14}$

For data analysis we used the French Discourse Analysis (DA) method, ${ }^{2}$ taking as basis the transcribed texts generated in the following dynamics of creativity and sensibility: lifeline and speaker map. The choice of this method of analysis was due to the fact that the production of meaning in the families' discourses could locate play in the sphere of personal experience and everyday events, which belongs to the microstructure of family relationships.

The movement of family discourse analysis occurred in stages: initially, the textual corpus was made less superficial, i.e. the linguistic surface, represented by the gross empirical material, was transformed into a discursive object after the 
linguistic materiality was reached, by using scores and considering the timing of each individual speech. $^{2}$

The analytical reading of the discursive object pointed to the indicative tracks that composed the analytical devices of theses subjects' discourses. This step aimed to search the discourse's text, preparing the analyst for the configuration of the discursive formation. By discursive formation it is understood that a given ideological formation, that is, a given position in a social historical context, determines what can and should be said. ${ }^{2}$

Subsequently, the passage from the discursive object to the discursive process occurred. At this stage, different discursive formations were related to ideological formation that rules these relationships. Finally, we reached the constitution of the discursive process, responsible for the sense of effect produced in the symbolic material. ${ }^{2}$

We emphasize that, in this method of analysis, analytical devices were used to reach the understanding of the meanings produced by the research participants. The devices identified in the discursive objectives were: paraphrase, the interdiscourse, and the unsaid.

\section{RESULTS AND DISCUSSION}

The analysis process led to the categorization of two thematic units: a happening about play; and playing in the course of the child's illness and treatment: a possibility to rescue care of maintaining life.

\section{Childhood cancer - a happening about play}

Becoming ill from cancer comes to the child as an event that represents a barrier to practice some play which she/he was used to doing: the disease, the infirmity [cancer] came into her life [child 6] in an age at which the child begins playing the coolest games: running, jumping and playing sports, but she cannot do any of that because of the treatment and the disease itself (Family 20, aunt of child 6); after she [child 5] began treatment there are things that she cannot do, like riding a bike, riding a scooter and play ball. These toys are stored downstairs in the house (Family 7 , sister of child 5).

This paraphrase was observed, in the family's discourse, a repetition of a characteristic speech, which refers to the idea that the disease itself modifies the types of games, especially the active ones, and that participation in sport is interrupted.

It is noteworthy that school age is the stage of childhood marked by the engagement of the child in active play such as running, playing ball, riding a scooter or bicycle, and sports practice. The family internalizes cancer and its treatment as impediments to the performance of such active play, common at school age.

Family members pointed out that the illness from cancer and its treatment act on the child's body, leaving him/her weakened, with limited mobility and no physical condition to play: she [child 7] totally changed pace. First, she underwent a very complicated surgery, then chemotherapy and radiotherapy... she was very weak: she had difficulty walking, balancing herself, but now she is recovering and she is walking well, but is still not balancing. After she started this treatment, she did not play anymore! (Family 22, mother of child 7); he [child 4] was very weakened because of the surgery and chemotherapy, he was not walking, do you understand? Then he lay all the time, he is not playing at all (Family 13, mother of child 4).

By the repetition of the speech, a characteristic of paraphrase, it was noted that the complexity of the disease and the types of treatment change the rhythm of a child's life: the surgery, the chemotherapy and the radiotherapy act on the child's body, leaving him/her impaired with limited mobility and balance, making the child lose the desire and the drive to play.

The family also talked about technological devices implanted in the body of the child, to follow up with treatment of the disease, as limiting the child in participating and interacting with others in the social environment in which they lived: he [child 4] likes to run and play ball, but I tell him not to play because of the valve [ventriculoperitoneal shunt - VPS] and the [semi-implanted central venous] catheter (Family 13, mother of child 4); after she [child 5] became ill, she did not ride anymore with the bike and the scooter, so as to not make any effort and cause the [semi-implanted central venous] catheter to move to another place (Family 16, mother of child 5); she [school 7] is no longer going to the pool or to the beach. It is not that she cannot go, it is to avoid getting the [semi-implanted central venous] catheter wet (Family 22, mother of child 7).

The family internalizes the VPS and the 
Semi-Implanted Central Venous Catheter (SICVC) as barriers to playing ball, riding a bike or a scooter. It is noteworthy that these technological devices are critical to the treatment of the disease, but they act as hindrances to some games that the children were used to, resulting in changes to their playing habits.

By the family reports, it is noted that these devices are internalized signs representative of limitations. One must remember that the signs are considered as mediation instruments of the psychological activities, such as memory and the accumulation of information. ${ }^{15}$ In this sense, the family has a memory of cancer as a sign that causes changes in the child's body and steals energy from childhood for the activity of play. More than that, the malaise that the disease and the treatment caused in the children is reframed by the family as a need for protection, counteracting the need for stimulation to continue with the growth and development, and maintaining those activities that gave pleasure to the child's life.

Despite the interest of the own child in maintaining their activities, the data indicated that the impact of the disease and the treatment on his/ her body caused physical restraint and organic indisposition, limiting the development of games. In this sense, nurses must work in partnership with the family and seek alternatives and adaptations together for play to meet the physical condition of the child..$^{2,16}$

The different types of cancer and its treatment modalities carry special health needs that require care, beyond enacting organic ailments, including: malaise, weight loss, bleeding, pain, inability to walk, lack of tactile sensitivity, hair loss, kyphosis, among others. ${ }^{2,16}$

In general, the demands of care were classified into four groups: development, modified lifestyle, technological devices, and medications. ${ }^{17}$ Technological care, which acquired prominence in the discourse of the family, was dispensed to children in need of some kind of technology to survive, such as central venous catheters and ventriculoperitoneal shunt, and were indicated by family as impediments to engaging in active play.

The nurse, when faced with such a situation, needs, to seek adjustments that will allow children to play, along with the family and the child, respecting their limits, drives and desires. To enhance the sources of revitalization for the child, without any risk to his/her life, without any damage to the physical integrity and complications to the treatment, and to talk to the child about his/ her limits and possibilities, should contribute to a sharing of responsibilities, while the child's right to actively participate in the treatment of disease and to continue playing is recognized.

\section{Playing in the course of the child's illness and treatment: a possibility to rescue care of maintaining life}

Disclosure of the diagnosis of childhood cancer motivated families to take their child to places such as the beach and other attractions, as well seeking sources of leisure, play and distraction: after we learned of her disease [cancer] [child 3], we went a day with her to the beach to say goodbye, that was before admission (Family 11, father of child 3); we [child 6] took her to the beach when we found about the problem [cancer], but before starting chemotherapy [...] and on the Sunday before surgery, we went to Christ the Redeemer to distract her a bit (Family 18, grandmother of child 6).

It is noticed that the period prior to hospitalization, and before the start of chemotherapy and the surgery, was composed of moments that motivated the family to organize and take the child on trips and sightseeing, to the beach, to attractions such as the Christ the Redeemer statue in Rio de Janeiro, to bid farewell to active play. It is part of the popular knowledge that cancer is a disease that requires a long and limiting treatment. Thus, in the interdiscourse of family, represented by the memory of the speech, the findings revealed that they took care of the children, seeking leisure time and preparing them for the passage through the disease and treatment process.

The disclosure of the diagnosis of childhood cancer is permeated by much suffering for the family, though they seek strength with a view to transmit it to the child. This attempt to transmit power to address the treatment may have motivated them to take walks on the beach and to go sightseeing before the start of treatment. ${ }^{18}$

Thus, based on what is not said by the family, we apprehend that among the repercussions suffered by the child due to cancer, lays the impossibility of walking outdoors and going to the beach. In this level, between the passage of the cancer diagnosis and the onset of treatment, the family took care of these children, seeking places 
of leisure to prepare them for the new phase that was approaching: the treatment of cancer.

Other family members reported that they worked actively to encourage their children to play, and sought to maintain as normal of a childhood as possible: I encourage her a lot, if I let it go, she [school 7] would not have a normal life, she stays indoors without playing and I say: you like to surrender to the disease... when I say this, she goes to play, so I know I have to stimulate; if I would allow it, she would not go out from inside the house [...] spends all day lying on the couch [...] if she gets like this, she will not play when it comes to adolescence and the study will be heavier and she will already be past the stage of playing. She has to return to her normal life (Family 21 , mother of child 7).

We notice that the child needed to be encouraged not to give up playing in order to preserve a normal lifestyle for her age. From this perspective, standardization should be perceived as a possibility for change and transformation, namely, the search for new possibilities for the maintenance of activities that generate well-being. ${ }^{19}$

One needs to remember that such a chronic condition, in which the child with cancer lives, is characterized for lasting an extended period of time. But that does not mean she always feel sick, because another feature of the chronic condition is related to the phase of exacerbation and remission. In this sense, during the period of remission, the child may feel ready to perform her activities. ${ }^{19}$ By stimulating children to continue playing during treatment, family members demonstrate that they appreciate play as a normal part of childhood. In this sense, they perform the role of promoters of normal growth and development of the child, in a process mediated by play. ${ }^{20}$

On the other hand, some family members recognized the importance of play for children, while they are able to point out the family's difficulties regarding the illness of the child and the need of care for their members, so that they feel encouraged and engaged in play: I think playing is missing in our family and especially in her life [child 6]. [...] We are in a very delicate moment, because of all the things that are happening in our family, the health problem, all that is moving us, moves a lot with everyone ... we have to try to help all the time, and playing can help (Family 20, aunt of child 6); she [child 6] complains because there is nobody to play with, she is not going to school [...] sometimes she gets sad, lying on the couch all day. She is in the need of play, to laugh, have fun, but I'm also sad about her illness, I'm depressed and without condition or desire to play (Family 18, grandmother of child 6).

We notice that relatives put the lack of play in the family and especially in the school setting within a context and recognize that play can help the child and the family in navigating the illness and treatment in a less traumatic manner.

We add that, despite the understanding of some family members about the importance of play for children, some of them reported feeling depressed, sad and unable to play with the child, confirming how childhood cancer is devastating for the family, and caution is necessary not only for those who have it, but also for their relatives. ${ }^{18}$ Cancer belongs to the rite of passage from a situation of normality to another one that demands coping with cancer treatment and its effects on the body and life of the child.

For two family members, the care given to children undergoing cancer treatment was guided by the nature of repair, at the expense of lifesustaining care: now, what I do is talk to her [child 6] to eat, to take some juice, sleep early, take the medicine to heal, get out of this condition of illness (Family 18, grandmother of child 6); she is not doing anything now, she does not play, but the time of treatment is for this very reason. It is just for treatment, nothing more! (Family 22, father of child 7).

The demands of care associated with the treatment of the disease, such as using medications and those targeted to the needs of daily living, such as nutrition, hydration, sleep and rest, take a central spot during cancer treatment. Thus, the focus of care becomes the treatment of illness and not only the care for the "being" of a child, with all its particularities and specificities of this stage of full biopsychosocial development.

In this case, during the cancer treatment, attention is focused on the disease that takes a main role, and the play activities assume a secondary value at this stage of a child's life. Along this same line of thought, a study in China showed that, although the scientific literature identified the benefits of play in the treatment of children with cancer, most Chinese parents view play as less important than medical care focused on disease. ${ }^{20}$ Despite the therapeutic benefits of play for sick children, this practice is still undervalued in our midst, and is considered a dispensable activity. ${ }^{21}$ 
It is the nurse, with care as a fundamental pillar of his/her practice within the genesis of the profession, who is the one who needs to dialogue with the family in order to show that maintaining play and playthings is an essential kind of care for the child, regardless of his/ her condition of illness, in addition to it being a child's right.

Other family members reported that they were still hoping and waiting for the moment of return of the child's play after the end of cancer treatment: in the hospital they [professionals] said that she [School 3] should be able to do it all again, only that we need to wait for the treatment to end (Family 11, father of child 3); the neuro [surgeon] told her [child 7] she will do whatever she wants, will play everything, but she needs only to recover her energy. He has stopped all the medicine; she is not taking anything anymore, just the chemo [therapy]. Everything in life passes, right? Today she is here, much better than before! After she finishes this treatment and she gets healed, and God willing she will be! She will do everything she did before (Family 21, mother of child 7).

The family awaits the end of the treatment and the cure of cancer for the child to continue the activities performed before the illness. However, it is known that after the period of treatment, social reintegration of a child must be monitored, as sometimes, the special health needs remain even after this step.

After completion of treatment these children may have some sort of sequelae, such as neurogenic bladder, renal failure, neurologic deficit, auditory deficit, visual deficit, paraplegia, hemiparesis, several amputations, endocrine disorders, drug addictions, report of difficulties in social adjustment, as well as posttraumatic stress. ${ }^{16,21-22}$ These sequelae, physical or psychological, deserve attention so that there is social reintegration of the child and family, aiming to overcome potential limitations resulting from the previous disease. ${ }^{23}$ Therefore, care focused on the maintenance of daily activities, including play, should be contemplated during and after cancer treatment.

\section{FINAL CONSIDERATIONS}

We apprehend that the illness from cancer in the history of the school-age child causedrepercussions that led to functional reductions that hindered the development of active play. Given these implications, care to maintain life, specific to the healthy time of the child's life, must be rescued with the objective of finidng ways to stimulate his/her potential.

The care and maintenance of life are employed in the search for strategies for the child to continue playing and interacting socially with his/her peers and relatives during treatment, since play, as well as the interactions, are sources of energy and revitalization. The nurse need to encourage and continue investing in the children's potential, respecting his/her organic and functional limitations, physical restrictions, lack of appetite and weakness. In this respect, there are alternatives for games, distractions and fun to be included in the treatment plan during hospitalization and at home.

Stimulation used by family members at home can occur in many situations. They can encourage the child to engage in the play practiced before the illness with their peers in the playground of the building, on the street, touring attractions of the city, at the beach, at the pool, at the park, encouraging them to socially interact and keep in touch with nature, because when there is encouragement, the child responds satisfactorily and feels more motivated to play. As for the need for participation of the family in stimulating the child, relatives should be included in the perspective of family-centered care, so that they feel encouraged to act as stimulating agents of child development.

The expectation of treatment completion and the cure of disease represented the possibility for the child to return to doing everything he/she did before the illness. Thus, during the course of illness and treatment, the focus of family care was to control the disease, and play took on a secondary value, while treating and healing was considered as a primary value. Thus, reparative care occupied the place of those care activities of maintenance, and the loss of active play was the biggest loss.

The end of treatment and the possibility of cure cannot be expected as the time for the child to return to their activities of the period before becoming ill. Life continues its flow, child development is a social need for health, and play is a child's right. Thus, the nurse must show relatives how to maintain daily activities within the possibilities of the child and the family, maintaining social interaction as part of the treatment.

Thus, it is concluded that the maintenance of play is a special health need that requires nursing care of a different nature. One needs to ensure 
the right of the child to play. Thus, nurses must assume the role of advocacy to defend this right, involving other professionals and family.

For the right to play to be guaranteed, the nurse needs to involve the family, and, side by side, professionals and family members should stimulate and encourage the child to make him/ her feel safe and comforted, and with it, to experience the disease process and treatment as best as possible, with less trauma and damage to his/her development.

\section{REFERENCES}

1. Ministério da Saúde (BR). Instituto Nacional do Câncer. Estimativa 2012 - Incidência de Câncer no Brasil. Brasília (DF): Instituto Nacional do Câncer, 2012 [acesso 2013 Jul 20]. Disponível em: http:/ / www1.inca.gov.br/estimativa/2012/ estimativa20122111.pdf

2. Silva LF, Cabral IE, Christoffel MM. The (im) possibilities of play for children with outpatient cancer treatment. Acta Paulis Enferm. 2010; 23(3):334-40.

3. Moraes JRMM, Cabral IE. A rede social de crianças com necessidades especiais de saúde na (in) visibilidade do cuidado de enfermagem. Rev LatinoAm Enferm [online]. Mar-Abr 2012 [acesso 2013 Jun 10]; 20(2):[08 telas]. Disponível em: http://www. scielo.br/pdf/rlae/v20n2/pt_10.pdf

4. National Center on Financing for Children with Special Health Care Needs. Florida (US): Chart Book CSHCN in Medicaid, SCHIP, and Title. V; 2004.

5. Pedro ICS, Galvão CM, Rocha SMM, Nascimento LC. Apoio social e famílias de crianças com câncer: revisão integrativa. Rev Latino-Am Enferm [online]. Mai-Jun. 2008 [acesso 2013 Jun 23]; 16(3):[08 telas]. Disponível em: http://www.scielo.br/pdf/rlae/ v16n3/pt_23.pdf

6. Amador DD, Gomes IP, Coutinho SED, Costa TNA, Collet N. Concepção dos enfermeiros acerca da capacitação no cuidado à criança com câncer. Texto Contexto Enferm. 2011 Jan-Mar; 20(1):94-101.

7. Morais FRC, Silva CMC, Ribeiro MCM, Pinto NRS, Santos I. Resgatando o cuidado de enfermagem como prática de manutenção da vida: concepções de Collière. Rev Enferm UERJ. 2011 Abr-Jun; 19(2):305-10.

8. Lima EC, Vargens OMC, Quitete JB, Macedo PO, Santos I. Aplicando concepções teórico-filosóficas de Collière para conceituar novas tecnologias do cuidar em enfermagem obstétrica. Rev Gaúcha Enferm. 2008 Set; 29(3):354-61.

9. Melo LL, Valle ERM. A brinquedoteca como possibilidade para desvelar o cotidiano da criança com câncer em tratamento ambulatorial. Rev Esc
Enferm USP. 2010 Jun; 44(2):517-25.

10. Ribeiro CA, Coutinho RM, Araujo TF, Souza VS. A world of procedures and worries: experience of children with a port-a-cath. Acta Paul Enferm [online]. 2009 [cited 2013- Jul 31]; 22(spe):93541. Available from:http://www.scielo.br/ pdf/ape/v22nspe/en_17.pdf

11. Li WH, Chung JO, Ho EK. The effectiveness of therapeutic play, using virtual reality computer games, in promoting the psychological well-being of children hospitalised with cancer. J Clin Nurs. 2011. Aug; 20(15-16):2135-43.

12. Groleau D, Cabral IE. Reconfiguring insufficient breast milk as a sociosomatic problem: mothers of premature babies using the kangaroo method in Brazil. Matern Child Nutr. 2009; 5(1):10-24.

13. 13. Silva LF, Cabral IE, Christoffel MM. Conhecendo a interação social nas brincadeiras das crianças com câncer em tratamento ambulatorial: subsídios para o cuidado de enfermagem. Rev Pesq Cuid Fundam [online]. Out-Dez. 2010. 2(Supl):63-7. Disponível em: http://www.seer.unirio.br/index.php/ cuidadofundamental/article/viewArticle/801

14. 14. Fontanella BJB, Luchesi BM, Saidel MGB, Ricas J, Turato ER, Melo DM. Amostragem em pesquisas qualitativas: proposta de procedimentos para constatar saturação teórica. Cad Saúde Pública. 2011 Fev; 27(2):389-94.

15. Zanolla SRS. O conceito de mediação em Vigotski e Adorno. Psicol Soc [online]. 2012, [acesso
2013 Jul 17]; 24(1):5-14. Disponível em: http:/ / www.scielo.br/pdf/psoc/v24n1/02.pdf

16. Silva LF. Significado do brincar para a família de crianças em tratamento oncológico: implicações para o cuidado de enfermagem [tese]. Rio de Janeiro (RJ): Universidade Federal do Rio de Janeiro. Programa de Pós-Graduação em Enfermagem; 2012.

17. Neves ET, Cabral IE. Empoderamento da mulher cuidadora de crianças com necessidades especiais de saúde. Texto Contexto Enferm [online]. 2008 Jul-Set [Acesso 2013 Jun 20]; 17(3):552-60. Disponível em: http://www.scielo.br/pdf/tce/ v17n3/a17v17n3.pdf

18. Santos LMP, Gonçalves LLC. Crianças com câncer: desvelando o significado do adoecimento atribuído por suas mães. Rev Enferm UERJ. 2008 Abr-Jun; 16(2):224-9.

19. Souza SPS, Lima RAG. Condição crônica e normalidade: rumo ao movimento que amplia a potência de agir e ser feliz. Rev Latino-Am Enferm [online]. 2007 Jan-Fev [acesso $2014 \quad$ F e v 04]; 15(1):156-64. Disponível em:http:// www.scielo.br/pdf/rlae/v15n1/pt_v15n1a23.pdf

20. Li HCW, Chung OKJ, Chiu SY. The impact of cancer on children's physical, emotional, and psychosocial well-being. Cancer Nurs. 2010 Jan-Feb; 33(1):47-54.

21. Kuperman H, Battistin C, Moreira ACF, Cornacchioni 
AL, Odone Filho C, Setian N, et al. Avaliação dos principais efeitos endócrinos tardios em crianças e adolescentes sobreviventes ao tratamento de neoplasias malignas. Arq Bras Endocrinol Metab [online]. 2010 [acesso $2013 \mathrm{Jul}$ 29]; 54(9):819-25. Disponível em: http://www.scielo.br/pdf/abem/ v54n9/a08v54n9.pdf

22. Boaventura CT, Araujo TCCF. Estresse póstraumático da criança sobrevivente de câncer e sua percepção acerca da experiência parental. Estud
Psicol [online]. 2012 [acesso $2013 \quad \mathrm{~J}$ u 1 29]; 17(2):283-90. Disponível em:http:// www.scielo.br/pdf/abem/v54n9/a08v54n9.pdf

23. Gomes IP, Lima KA, Rodrigues LV, Lima RAG, Collet $\mathrm{N}$. Do diagnóstico à sobrevivência do câncer infantil: perspectiva de crianças. Texto Contexto Enferm. 2013 Jul-Set; 22(3):671-9. Disponível em: http://www.scielo.br/pdf/tce/v22n3/v22n3a13 $\mathrm{pdf}$ 